\title{
PROBLEMY RELIGIJNE ARABII SAUDYJSKIEJ
}

DOI: http://dx.doi.org/10.12775/TiCz.2015.027

\section{WSTĘP}

Od wielu już lat społeczność międzynarodowa zwykła uważać, iż Arabia Saudyjska to kraj, w którym występuje niemal całkowity brak tolerancji wobec innowierców. Informacje te potwierdzają w znacznej mierze liczne badania, które często odnotowują konkretne przypadki łamania praw człowieka w tym kraju. Równocześnie osoba Osamy Bin Ladena, uznawanego za międzynarodowego terrorystę, kojarzonego właśnie z Arabią Saudyjską, spotęgowała przytoczoną opinię.

Bez wątpienia kraj ten nie jest jedynym na Bliskim Wschodzie, który kojarzony jest $\mathrm{z}$ brakiem tolerancji oraz terroryzmem. Trzeba jednak zauważyć, że zdecydowanie Arabia Saudyjska ma swoją specyfikę wśród innych krajów tego regionu. Polega ona na odmiennej doktrynie w zakresie islamu. O ile można przyjąć, iż np. Iran, zamieszkały przez Persów, zdominowany jest przez doktrynę szyicką, Irak także przez szyitów, któ-

* Marcin Imach jest pracownikiem naukowym na Wydziale Teologicznym Uniwersytetu Śląskiego w Katowicach. 
rymi jednak prawie zawsze rządzili sunnici, o tyle w Arabii Saudyjskiej dominuje wahhabizm ${ }^{1}$. Zwykło się uważać, iż to właśnie ten nurt islamu odpowiedzialny jest za aktualne postrzeganie tego saudyjskiego kraju przez międzynarodową opinię publiczną jako wspierającego terroryzm. Dlatego też wydaje się interesujące zweryfikowanie, na ile ta doktryna wywarła wpływ na Arabię Saudyjską, na kształt obecnego państwa. Równocześnie nie można wykluczyć, że w toku analizy okaże się, że opinia o tym kraju nie oddaje stanu faktycznego. Nie można przecież przyjąć bez odpowiedniej analizy za pewnik, iż wahhabizm wywarł wpływ na Arabię Saudyjską. Można wręcz zadać pytanie, które zdaje się powinno być pierwsze w kolejności, a mianowicie czy wahhabizm to doktryna, która niejako daje podstawy dla współczesnego braku tolerancji religijnej oraz terroryzmu? Odpowiedzi na wszystkie te pytania powinny pomóc w odpowiedzi na zasadnicze pytanie, które brzmi: czy rzeczywiście Arabia Saudyjska jako kraj o wahhabickiej doktrynie islamu ma podstawy do bycia krajem nietolerancyjnym religijnie oraz wspierającym międzynarodowy terroryzm? Równocześnie uzyskanie takiej odpowiedzi jest też celem tego artykułu. Tym samym określenie w pytaniu, czy ma podstawy, zakłada, że nie jest narzucone już we wstępie stanowisko, iż Arabia Saudyjska jest, czy też nie jest, krajem nietolerancyjnym i wspierającym terroryzm. Dla jego osiągnięcia w pierwszej części pracy ukazana zostanie sytuacja na terenie obecnej Arabii Saudyjskiej przed pojawieniem się wahhabizmu. Następnie zostaną przedstawione dzieje tej doktryny „współpracującej” z Saudami przed uzyskaniem niepodległości przez Arabię Saudyjską. Kolejny punkt artykułu zostanie poświęcony niepodległemu państwu w XX w. Z kolei następna część pracy ma za zadanie przedstawienie wahhabizmu w Arabii Saudyjskiej w XXI w. Wszystkie te części pracy powinny pomóc w uzyskaniu odpowiedzi na przedstawione powyżej zasadnicze pytanie.

\section{DAWNE TRADYCJE}

W celu uzyskania odpowiedzi, czy obecna Arabia Saudyjska wraz z doktryną wahhabicką ma podstawy do bycia krajem nietolerancyjnym religijnie oraz wspierającym terroryzm, konieczne wydaje się zapoznaniem

${ }^{1}$ W literaturze przedmiotu spotkać można zarówno wahabizm, jak i wahhabizm. 
z tym krajem, jego specyfiką. Dlatego też w niniejszym punkcie przedstawione zostaną pewne tradycje związane z obszarem dzisiejszej Arabii Saudyjskiej w okresie przed pojawieniem się przedmiotowej doktryny. Już na początku należałoby sprecyzować, jaki dokładnie teren będzie przedmiotem pewnej analizy. Otóż trzeba zaznaczyć, że obszar obecnej Arabii Saudyjskiej zajmuje znaczącą część Półwyspu Arabskiego. Zajmowanie się tak wielkim obszarem mogłoby wydawać się kłopotliwe, gdyby nie fakt, że ten duży teren jest $\mathrm{w}$ większości pokryty pustynią ${ }^{2}$.

Ziemie te już $\mathrm{w}$ dawnych czasach znane były ze znacznej religijności ludności, która je zamieszkiwała. Potwierdzeniem tego jest al-Kaba jako obecnie najważniejsze sanktuarium islamu, które bywa często określane mianem „Domu bożego”. Z kolei znajdujący się w niej Czarny Kamień jest największą świętością muzułmanów. Warto zauważyć, że al-Kaba istniała jako miejsce kultu już w II w. po Chrystusie, a więc na długo przed pojawieniem się islamu ${ }^{3}$.

Trzeba także zauważyć, iż to w okresie przedmuzułmańskim najsłynniejsze i najczęściej odwiedzane wyrocznie znajdowały się właśnie w Mekce we wspomnianej świątyni al-Kaba. W czasach przedmuzułmańskich świątynia ta była poświęcona bóstwu o imieniu Hubal. Podobne znaczenie miała świątynia $\mathrm{Zu}$ al-Chalasy w Tabali ${ }^{4}$. Należy tu nadmienić, iż bez wątpienia na terenie obecnej Arabii Saudyjskiej w czasach przedmuzułmańskich żyli także chrześcijanie. Gdy jednak w VII w. islam wchodził na teren dzisiejszej Arabii Saudyjskiej, wszystkich chrześcijan wypędzono ${ }^{5}$. Można byłoby zatem przyjąć, że był to przejaw znacznego braku tolerancji wobec innych religii ze strony muzułmanów. Jednocześnie stanowiłoby to podstawę do wyciągnięcia sądu, że już pierwsi muzułmanie stanowili pewną podstawę dla ewentualnej nietolerancji współczesnej wahhabickiej Arabii Saudyjskiej. Potomkami tamtych muzułmanów są jednak także szyici i sunnici żyjący w różnych krajach, którzy często nie są nietolerancyjni. Należy też zauważyć, iż zanim doszło do wypędzenia chrześcijan w 615 roku, nastąpiła hidżra grupy muzułmanów, którzy na

\footnotetext{
${ }^{2}$ K. Kościelniak, Dżihad. Święta wojna w islamie, Kraków 2002, s. 111 i n.

${ }^{3}$ M. Dziekan, Symbolika arabsko-muzutmańska, Warszawa 1997, s. 47.

4 Tenże, Arabia Magica, Warszawa 1993, s. 68 i n.

${ }^{5}$ K. Kościelniak, Dżihad. Święta, s. 111 i n.
} 
polecenie Mahometa udali się z Mekki do królestwa Aksum w Abisynii, gdzie wyznawano chrześcijański monofizytyzm. Była to w pewnym sensie przyjacielska wizyta osób wierzących w Jednego Boga. Nie był to jednak koniec kontaktów obu religii w tamtym okresie. Otóż około 628 roku Mahomet przyjął delegację chrześcijan z Nadżranu ${ }^{6}$. Zostali oni opisani przez muzułmanów jako wielcy znawcy religii chrześcijańskiej. Prawdopodobnie muzułmanie wiedzieli wówczas, że owa grupa chrześcijan była poważana także w Bizancjum ze względu na swoją wiedzę religijną. Jednocześnie chrześcijanom z Nadżranu pozwolono wówczas pomodlić się w meczecie ${ }^{7}$. Trudno byłoby zatem dostrzec tu pewną skłonność do nienawiści do innowierców, która miałaby w przyszłej Arabii Saudyjskiej zaowocować terroryzmem. Interesujące wydaje się także to, że na terenie Arabii w przypadku życia rodzinnego niewiele się zmieniło w stosunku do okresu przedmuzułmańskiego. Informacje o dużym znaczeniu życia rodzinnego u Arabów potwierdza F. Wight, przyznając, że na Bliskim Wschodzie w zasadzie rodzina to małe królestwo. Z kolei najwyższym jego władcą był ojciec. Równocześnie niejako każda grupa musiała posiadać własnego „ojca”. Jak łatwo można zatem zauważyć, dla arabskiej ludności z terenu obecnej Arabii Saudyjskiej ogromne znaczenie miało życie rodzinne, plemienne. Bez wątpienia spory religijne nie były tym problemem, który nurtował przeciętną rodzinę z tamtych czasów. Oczywiście można w takiej sytuacji przyznać, że również obecnie terroryzmem nie są przeważnie zainteresowane tzw. przeciętne rodziny, a konkretne ugrupowania. Z drugiej jednak strony należy dostrzec, iż Mahomet w ostatnich latach swojego życia nakazał oczyścić Arabię z niewiernych. Miało to nastąpić od Adenu aż do Iraku oraz od Dżuddy aż do Syrii. W testamencie Mahometa, którym posługiwano się po jego śmierci, znajdowało się stwierdzenie dotyczące konieczności wypędzenia Żydów i chrześcijan z Półwyspu Arabskiego9. Na pewno jest to czynnik, który można byłoby uznać za determinant obecnego postępowania fundamentalistycznych

${ }^{6}$ Nadżran jest obecnie miastem w południowej Arabii Saudyjskiej, niedaleko granicy z Jemenem.

${ }^{7}$ H. Goddard, Historia stosunków chrześcijańsko-muzutmańskich, przeł. S. Zalewski, Warszawa 2009, s. 34-47.

${ }^{8}$ F. Wight, Obyczaje krajów biblijnych, Warszawa 1999, s. 89.

9 A. Borowski, Islam, Katowice 2009, s. 133. 
Arabów. Równocześnie trzeba też przyznać, iż polecenie Mahometa dotyczyło obowiązku wszystkich muzułmanów, a przestrzegane byłoby głównie przez wahhabitów, którzy nie do końca uznają autorytet Proroka. Wydaje się zatem, że ta argumentacja nie jest wystarczająca w konfrontacji z obecną różnorodnością odmian islamu. Pewnym zaprzeczeniem przytoczonego zdania $\mathrm{z}$ testamentu Mahometa wydaje się myśl muzułmańskiego filozofa al-Tabariego (838-923). Był on znanym komentatorem Koranu i twierdził, że muzułmanie kochają niewiernych, jednak to uczucie nie jest przeważnie odwzajemniane ${ }^{10}$. Równocześnie istnieją pewne informacje przyznające, iż ludność Arabii była już w dawniejszych czasach raczej przyjaźnie nastawiona do Europejczyków, czyli niewiernych. Informacje te potwierdzali podróżnicy z duńskiej ekspedycji z roku 1762 (wtedy przybyli do Dziddy). Stwierdzili oni, że nie czuli się skrępowani, chodząc po ulicach arabskich miast ${ }^{11}$.

Jak łatwo można było dostrzec, rozwój islamu opierał się na pewnej przemocy wobec niewiernych. Jednocześnie tzw. przeciętne rodziny muzułmańskie nie wykazywały zbytniego zainteresowania tematem niewiernych. Tym samym, biorąc pod uwagę, że potomkami pierwszych muzułmanów są zarówno szyici z Iranu i Iraku, jak również sunnici z innych krajów arabskich, a terroryzm czy brak tolerancji nie zawsze u nich występuje, trudno określić, że pierwotne czasy okresu muzułmańskiego wywarły wpływ na wahhabizm w obecnej Arabii Saudyjskiej w stopniu determinującym jego nietolerancję czy też przemoc.

\section{ARABIA SAUDYJSKA W OKRESIE PRZEDPAŃSTWOWYM}

Jak można przyjąć, samo pojawienie się islamu na terenie dzisiejszej Arabii Saudyjskiej nie stało się przyczyną obecnego stanu rzeczy, a więc tego, jak ten kraj jest dzisiaj postrzegany. Konieczne wydaje się prześledzenie losów tego obszaru od czasu pojawienia się doktryny wahhabickiej.

10 S. Ismail, Podstawowe zasady „,non violence” $w$ islamie, w: Chrześcijanie i muzułmanie razem dla pokoju, red. M. Kozubek, T. Czakański, W. Sztyka, Katowice 2012, s. 106.

11 T. Hansen, Arabia Felix, przeł. M. Przymanowska, Warszawa 1968, s. 152. 
Dlatego też w niniejszym punkcie spróbujemy prześledzić dzieje wahhabizmu w okresie przedpaństwowym. Obecnie Arabia Saudyjska to bez wątpienia pewne połączenie Saudów z koncepcją wahhabicką. Dlatego też oprócz zajmowania się tylko samą doktryną należy także dostrzec połączone $\mathrm{z}$ nią dzieje tego plemienia. Otóż z dużym prawdopodobieństwem można przyjąć, iż Saudowie wywodzą się z osiadłej grupy, która założyła Dirijję. Równocześnie uznaje się, że byli oni pierwotnie klasą posiadającą ziemię. Prawdopodobnie byli to głównie kupcy pochodzący z Nadżdu. Jedną z najbardziej znanych postaci spośród tego plemienia był Muhammad ibn Saud, który zmarł w 1765 roku. Początkowo Saudowie ograniczali się do małej osady Dirijja. Ich dzieje nabrały nowych barw, dopiero gdy przyjęli doktrynę religijną wahhabizmu. Jej twórcą z kolei był Muhhamad ibn Abd al-Wahhab ${ }^{12}$. Informacje te potwierdza także K. Kościelniak, który przyznaje, iż w Arabii w XVIII w. największe znaczenie zyskał ruch islamski zwany wahhabizmem. Nazwa powstała od Ibn’Abda al-Wahhaba (1703-1792). Można spostrzec, że główną cechą jego poglądów był bardzo silny monoteizm. Stało się to podstawą odrzucenia kultu świętych, czci zmarłych, sufickich obrzędów, posługiwania się amuletami, spożywania alkoholu, palenia tytoniu, dawania schronienia heretykom i przyjaźni z innowiercami. Jego celem było wprowadzenie ustroju państwowego opartego na islamie hanbalickim. Po pewnym czasie zwolennicy wahhabizmu wypowiedzieli świętą wojnę w zasadzie wszystkim, którzy nie chcieli przyjąć tego kierunku. Można wręcz stwierdzić, iż umacnianie się tego kierunku w XIX w. było przygotowaniem do powstania Arabii Saudyjskiej ${ }^{13}$. Bez wątpienia takie poglądy, pochodzące z XVIII w., można byłoby uznać za podwaliny współczesnego braku tolerancji w Arabii Saudyjskiej oraz wspierania przez część jej mieszkańców terroryzmu. Jednakże trzeba też zauważyć, że Abdel Wahhab nie stworzył swojej koncepcji całkowicie nowatorsko. Jak zostało to już wspomniane, korzystał z dorobku hanbalickiego. Należy wręcz uznać, iż czerpał w tworzonym przez siebie ruchu z prac Ahmeda Ibn Hanbala (zm. 855 r.). Stworzył on właśnie tzw. hanbalizm, pewien nurt $\mathrm{w}$ islamie negujący wszelkie inne pisma niż

12 M. al-Rasheed, Historia Arabii Saudyjskiej, przeł. K. Pachniak, Warszawa 2011, s. $43-55$.

${ }^{13}$ K. Kościelniak, Dżihad. Święta, s. 55-57. 
Koran i komentarze Proroka. Według zwolenników tego nurtu to postęp powinien dostosować się do Koranu, a nie odwrotnie. Równocześnie Abdel Wahab korzystał także z poglądów innego teologa hanbalickiego Ibn Tajmiji. Natomiast Mahometa uznał za zwykłego człowieka, co prawda wybranego przez Boga. Można zatem podsumować, że nurt wahhabicki zbudował system prawny odwołujący się jedynie do tekstów objawionych, czyli Koranu i sunny. Równocześnie zaczęto je stawiać ponad wszystkie inne źródła prawa ${ }^{14}$. Trzeba tu zaznaczyć, że pojawienie się al-Wahhabiego z jego doktryną nie było czymś całkowicie nadzwyczajnym w świecie islamu. Wynika to $\mathrm{z}$ tego, iż bez wątpienia jednym z etapów, w których kształtowało się prawodawstwo islamskie, było powstawanie szkół sunnickich. Przyjmowały one przeważnie nazwy od swoich twórców. Dlatego też uznaje się, że wahhabizm miał swoje podstawy we wspomnianej szkole hanbalickiej ${ }^{15}$.

Zapewne ważną tezą wahhabizmu było to, iż al-Wahhab postulował także zakaz przyjaźnienia się z osobami innej wiary. Dlatego też przyjmuje się, że nawet współczesny wahhabizm uznaje, iż należy prowadzić świętą wojnę $\mathrm{z}$ niewiernymi ${ }^{16}$. Oczywiście powstaje pytanie, czy ten sposób myślenia nie jest zbyt dużym uproszczeniem. Czy z pewnego postulatu sprzed ponad dwustu lat można wnioskować, jaka jest obecna doktryna w sprawie nietolerancji i terroryzmu w Arabii Saudyjskiej? Na to pytanie odpowiedzą zapewne kolejne punkty artykułu, gdzie przedstawione zostaną czasy państwowości tego kraju. W danym momencie trzeba jednak odnotować, iż taki postulat ze strony twórcy tego nurtu został podyktowany. Równocześnie jeżeli przyjąć, iż al-Wahhab nakazywał posługiwanie się jedynie Koranem oraz sunną, to trzeba zauważyć, że o ile co do Koranu występuje duża jasność, czym jest i co zawiera, o tyle należy przyznać, iż uznaje się, że sunna zawiera zarówno słowa, jak i czyny Mahometa, jak również pierwszych jego zwolenników ${ }^{17}$.

${ }^{14}$ G. Małachowski, System konstytucyjny Arabii Saudyjskiej, Warszawa 2011, s. $14-26$.

15 E. Sakowicz, Czy islam jest religia terrorystów?, Kraków 2002, s. 104.

16 Tamże, s. 204.

17 K. Bukowski, Religie świata wobec chrześcijaństwa, Kraków 1999, s. 84. 
Bez wątpienia istotne $z$ punktu widzenia odpowiedzi na kluczowe pytanie zawarte w tym artykule wydawać się może to, iż al-Wahhab nakazał, aby wierni odpowiadali na wezwania przywódcy muzułmańskiego do świętej wojny, która miałaby zostać wymierzona przeciw osobom nieprzestrzegającym wyznaczonych zasad. Trzeba tu także zauważyć, iż do herezji w tym przypadku zaliczał również kult świętych oraz odwiedzanie grobów świętych mężów i składanie im ofiar. Z drugiej strony trzeba zaznaczyć, że istotne było także to, że zachęcał społeczność muzułmańską do wspólnych modlitw. Wszystko to spowodowało, iż wahabizm nie spodobał się wszystkim Arabom z tej części Półwyspu. Otóż o ile początkowo emir Ujajny sprzyjał reformatorowi, to jednak po pewnym czasie wypędził go. Był to w dużej mierze efekt ogromnych reform, które w tym mieście wprowadził al-Wahhab. W czasie swojego pobytu w tej osadzie doprowadził do publicznego ukamienowania kobiet oskarżonych o prostytucję, zachęcał do nakładania kar na osoby, które odmawiały wspólnych modlitw. Prawdopodobnie doktryna ta do tego stopnia nie spodobała się wielu Arabom, iż inni emirowie poprosili emira Ujajny o zamordowanie reformatora. Emir obawiał się jednak rozłamu wspólnoty, dlatego zaledwie poprosił al-Wahhabiego o opuszczenie osady. Przybył on wówczas do Dirijji, której emir był z rodu Saudów. Pakt pomiędzy al-Wahhabim a emirem saudyjskim został zawarty w roku 1744. Doszło wówczas do podziału władzy w tej osadzie. Otóż emir został imamem społeczności i zobowiązał się prowadzić dżihad przeciw niewiernym. Natomiast al-Wahhabi został przywódcą religijnym. Saudyjski władca stał się w ten sposób przywódcą całej tamtejszej społeczności. Dla reformatora zbudowano meczet, w którym wygłaszał swoje nauki. W zasadzie można przyjąć, iż od tego momentu rozpoczęła się ekspansja terytorialna saudyjsko-wahhabicka. Na podporządkowanym obszarze Saudyjczycy wymuszali na tubylczej ludności posłuszeństwo wobec wahhabickiego islamu. Bez wątpienia w tym przypadku to właśnie nauka o dżihadzie umożliwiła Saudom podbój okolicznych terenów. Do głównych zasad wahhabizmu zaliczano przecież konieczność misji wahhabickiej oraz oczyszczenie Arabii z innych religii. Istotne było także narzucenie całej Arabii prawa szariatu. Przyjmuje się, że to mieszkańcy w południowym Nadżdzie przyjęli po Dirijji jako pierwsi wahabizm i byli gotowi wyruszyć na wojnę religijną. Powstała w ten sposób pewna konfederacja plemion pod pro- 
tektoratem saudyjsko-wahhabickim, która miała często jeden cel, którym był wspólny udział w podziale łupów ${ }^{18}$. Jeżeli przyjąć ten ostatni cel za zasadniczy, to na pewno trudno byłoby jednoznacznie uznać, iż przemoc stosowana w tamtym czasie dla poszerzania wiary wahhabickiej ma swoje odzwierciedlenie w obecnej Arabii Saudyjskiej. Nie można równocześnie nie dostrzec tego, że pomimo ogromnego nacisku na szerzenie wiary już w XIX w. władcy muzułmańscy otworzyli szereg nowych szkół, które zajmowały się głównie kształceniem w dziedzinach świeckich ${ }^{19}$. Równocześnie jeżeli przyjąć, iż wpływy wahhabizmu oraz propagujących go Saudów zwiększały się wskutek działań wojennych, to jednak trzeba przyznać, że nie sam przymus doprowadzał do poszerzania wpływów. Otóż teologia wahabbizmu była dla wielu Arabów ogromną pokusą. Wahhabizm obiecywał przecież nie tylko w obecnym świecie zbawienie. Interesująca była także dla nomadów pewna doktryna jedności. Twierdzi się także, iż dzięki wahhabizmowi udało się osiągnąć pewną symbiozę pomiędzy ludnością osiadłą a nomadami. Bez wątpienia wszystko to doprowadziło do sytuacji, w której jeszcze przed 1792 rokiem Saudowie podporządkowali sobie Rijad, Chardż, Kasim. Wyznaczano wówczas wahabickich sędziów, których zadaniem było szerzenie nowego ładu oraz jego przestrzeganie. Z kolei emirowie z Nadżdu zostali podporządkowani władzy Saudów za sprawą szerzenia wahabizmu. Równocześnie zostali zmuszeni do płacenia zakatu Saudom. Gdy Saudowie opanowali już środkową Arabię, ich celem stała się al-Hasa, którą zamieszkiwali szyici. Następnie celem stało się wybrzeże Zatoki Perskiej i Omanu. Ekspansja była zatem szybka. Już w 1797 roku Katar przyjął wahhabizm, co następnie uczynił także Bahrajn. Z miejsc tych płynął dla Saudów dodatkowy zakat. Łatwo zatem można zauważyć, że owa ekspansja saudyjsko-wahhabicka doprowadzała do sytuacji, w której skarbiec Saudów stawał się coraz pełniejszy.

Podczas owych podbojów dochodziło często do wydarzeń, które nie mogły być tolerowane przez innych muzułmanów. Otóż np. po opanowaniu Mekki i Medyny na początku XIX w. Saudowie nakazali zniszczenie grobów Proroka i kalifów. Wynikało to z wahhabickiej nauki

${ }_{18}$ M. al-Rasheed, Historia Arabii, s. 43-55.

19 E. Sakowicz, Edukacja $w$ islamie - czasy nowoczesne $i$ wspótczesne, w: J. Różański (red.), Misje i religie, Górna Grupa 2014, s. 227. 
zabraniającej wznoszenia budowli na mogiłach. Z kolei gdy wojskom wahhabickim nie udało się opanować Jemenu, Saudowie zaczęli na początku XIX w. zagrażać Imperium Osmańskiemu. Wówczas to w 1801 roku splądrowali Karbalę, święte miasto szyitów. Wojska saudyjsko-wahhabickie nie były jednak w stanie opanować zarówno Mezopotamii, jak i Syrii. Te tereny były przez nich jedynie plądrowane. Doprowadziło to do sytuacji, w której wielu muzułmanów pozostało przy swojej wierze. Natomiast wspomniane splądrowanie szyickiej Karbali oraz innych miast szyickich wywołało ogromny gniew szyitów, tak iż w Darijji w 1803 roku zamordowali oni w meczecie saudyjskiego przywódcę. Następnie Saudyjczycy musieli się zmagać z ofensywą Egipcjan oraz Turków, którzy od dłuższego czasu chcieli położyć kres przemocy stosowanej przez Saudów w imię wahhabizmu. Ostatecznie w jej efekcie w 1818 roku zdobyto stolicę Saudów Dirijję, która została splądrowana, a przywódcy wahhabiccy straceni. Wydawało się wówczas, że wahhabizm zostanie zapomniany. Gdy jednak w 1824 roku obce wojska wycofały się, udało się w okrojonej formie wznowić emirat saudyjsko-wahhabicki. Przez kolejne lata trwały wewnętrzne walki pomiędzy przywódcami wahabickimi o prymat. Po znacznych perturbacjach Saudom udało im się utrzymać władze w Rijadzie do 1871 roku. Jednocześnie wewnętrzne walki trwały praktycznie do końca XIX w. ${ }^{20}$

Bez wątpienia powyższy punkt pracy ukazał skutki połączenia organizmu Saudejczyków z koncepcją wahhabizmu. Okazało się, że Saudyjczykom dzięki tej koncepcji udało się osiągnąć ogromny wzrost znaczenia, prestiżu, terytorium. Podboje, które nastąpiły, mogą się bez wątpienia kojarzyć z tymi znanymi z VII w., gdy islam pojawił się i bardzo szybko rozprzestrzenił za pomocą miecza na terenie Bliskiego Wschodu oraz w Afryce Północnej. Trudno byłoby zatem uznać, iż państwo saudyjsko-wahhabickie zachowywało się w jakiś nowatorski sposób. Podbój terytorialny związany z rozpowszechnianiem religii, jak również władzy, nie był niczym nowym. Nie można zatem stwierdzić, że sama koncepcja wahhabicka, jak i jej połączenie z organizmem Saudyjczyków stanowiły podstawę dla przyszłego postrzegania Arabii Saudyjskiej jako kraju o braku tolerancji religijnej czy wręcz terrorystycznego. Należy oczywiście

${ }^{20}$ M. al-Rasheed, Historia Arabii, s. 43-55. 
pamiętać, że takie stwierdzenie ma sens tylko wtedy, gdy odniesiemy je do innych krajów arabskich regionu.

\section{DOKTRYNA WAHHABICKA WE WSPÓŁCZESNEJ ARABII SAUDYJSKIEJ XX W.}

Przyjęcie doktryny wahhabickiej przez Saudów spowodowało ich znaczną ekspansję terytorialną. Co prawda zdobycie ich stolicy przez Ottomanów doprowadziło do fiaska tej koncepcji w zakresie państwowości, jednak ten krótki okres połączenia Saudyjczyków i wahhabizmu ukazał pewną wrogość tej koncepcji wobec innych nurtów islamu. Powstaje zatem pytanie: czy znalazło to swój wyraz w niepodległym państwie, jakim stała się Arabia Saudyjska? Odpowiedzi na to pytanie spróbujemy udzielić poniżej. Otóż niepodległe Królestwo Arabii Saudyjskiej powstało w 1932 roku przy oficjalnym wsparciu islamu wahabickiego. Ogromne znaczenie w tym przypadku miało swoiste połączenie systemu państwowego $\mathrm{z}$ wahhabizmem, które ponownie doprowadziło do jeszcze większego rozpowszechnienia się tego kierunku ${ }^{21}$. Należy jednak zauważyć, iż zanim wszystkie te fakty nastąpiły, to przez dwa pierwsze dziesięciolecia XX w. nadal trwały wewnętrzne walki na terenie obecnej Arabii Saudyjskiej, aczkolwiek Saudowie coraz bardziej umacniali swoje pozycje ${ }^{22}$. Można wręcz stwierdzić, że właśnie dopiero pewna znaczna ponowna dominacja Saudów na tym terenie doprowadziła do tego, że w 1932 roku proklamowano Królestwo Arabii Saudyjskiej ${ }^{23}$. W okresie tym kraj ten należał do najsłabiej rozwiniętych na świecie. Przyjmuje się obecnie, iż jednym z czynników, które wywarły znaczny wpływ na pewne zacofanie cywilizacyjno-kulturalne ludów arabskich, było znaczące przywiązanie do tradycji. Jeszcze podczas koczowniczego trybu życia Arabów tradycja była przekazywana z pokolenia na pokolenie. Jednocześnie owa tradycja wyróżniała Saudów wśród innych ludów arabskich ${ }^{24}$. Jednak w początkowych latach niepodległego państwa to inny czynnik zaważył na jego egzy-

${ }^{21}$ K. Kościelniak, Dżihad. Święta, s. 55-57.

${ }^{22}$ M. al-Rasheed, Historia Arabii, s. 70-75.

23 Tamże, s. 107.

${ }^{24}$ A. Mrozek, Średniowieczna filozofia arabska, Warszawa 1967, s. 234. 
stencji. Otóż w okresie tym odkryto ogromne złoża ropy naftowej w tym kraju. Po czasie okazało się, że ten pustynny kraj posiada 25\% wszystkich znanych zasobów ropy naftowej ${ }^{25}$. Prawdopodobnie również dlatego Madawi al-Rasheed ${ }^{26}$ pisała, że bez wątpienia ważne wydarzenie dla Arabii Saudyjskiej nastąpiło w 1933 roku, kiedy to jej minister finansów podpisał z amerykańską spółką Standard Oil of California porozumienie w sprawie poszukiwania złóż ropy naftowej. Wówczas istotne okazało się pewne problematyczne uzasadnienie współpracy z niewiernymi. Trzeba tu zaznaczyć, iż jeszcze na rok przed podpisaniem tego porozumienia Arabię Saudyjską zamieszkiwało mniej niż pięćdziesięciu niemuzułmanów. Był to czas dotkliwy dla Saudów pod względem finansowym. Ze względu na światowy kryzys zmniejszyła się liczba pielgrzymów przybywających do Mekki. O ile jeszcze w 1930 roku było to 100 tys., to już w 1933 roku tylko 20 tys. ${ }^{27}$ Zatem determinacja w poszukiwaniu pieniędzy była główną przyczyną współpracy z niewiernymi.

Saudowie u początków swej państwowości poza problemami finansowymi borykali się jeszcze ze sporym kompleksem, który zapewne mieli już od dawna. Należy tu przypomnieć, że w odróżnieniu od wielkich rodów panujących w Jordanii czy Maroku nie mogli poszczycić się pokrewieństwem z Prorokiem, mimo że strzegli Świętych Miejsc islamu ${ }^{28}$. Prawdopodobnie było to także powodem tego, iż w swoim państwie chętnie przyjęli doktrynę wahhabizmu, który w pewnym sensie wyróżniał ich spośród innych plemion arabskich. Można wręcz stwierdzić, iż początkowe ich poniżenie jako tych, którzy nie są godni w pewnym sensie Proroka, zamieniło się w ich wywyższenie jako tych, którzy jako jedyni znali jedyną właściwą interpretację islamu, nawiązującą do początków tej religii, a równocześnie odrzucającą pewien kult jej twórcy - Mahometa.

W pewnym sensie w ramach tej doktryny w 1953 roku utworzono w Arabii Saudyjskiej organizację Hizb al-Tahrir al-Islam. Uznawała ona dżihad za środek, który powinien mobilizować jej członków do walki z niewiernymi, aczkolwiek nie było ich celem obalenie reżimów z Bli-

${ }^{25}$ K. Kościelniak, Dżihad. Święta, s. 111 i n.

${ }^{26}$ Madawi al-Rasheed specjalizuje się w historii Arabii Saudyjskiej, pracuje w King's College w Londynie.

27 M. al-Rasheed, Historia Arabii, s. 129-133.

${ }_{28}$ G. Małachowski, System konstytucyjny, s. 29. 
skiego Wschodu przy użyciu siły. Organizacja ta wyrażała chęć zdobycia tak dużego poparcia społecznego, iż pewnego dnia byłaby w stanie drogą pokojową obalić wspomniane reżimy ${ }^{29}$. Istotne $\mathrm{w}$ tym przypadku jest to, iż po pewnym czasie doszło jednak do rozdzielenie Hizb al-Tahrir od ruchu wahabitów, którzy chcieli wcielać prawo szariatu drogą wojenną ${ }^{30}$. Zatem nawet pewne organizacje, które powstawały w Arabii Saudyjskiej, a miały obiegowa opinię terrorystycznych, nie były nimi w istocie. Nurt wahhabizmu co prawda niejako domagał się dżihadu miecza, jednak pozostawał on tylko w teorii.

Bez wątpienia spokój religijny w kraju był wynikiem także pewnego wzrostu zamożności i relatywnego dobrobytu mieszkańców. Trzeba wspomnieć, że dopiero w latach pięćdziesiątych XX w. część Saudyjczyków mogła korzystać z publicznych usług medycznych, szpitali i szkół ${ }^{31}$. Równocześnie lata te to okres walk wewnętrznych pomiędzy synami zmarłego króla, które nawet zagrażały istnieniu państwa ${ }^{32}$. Zatem tym, co najbardziej interesowało w tym okresie przywódców saudyjskich, była władza oraz wynikające z niej korzyści. Trudno byłoby zatem przyznać, że istnieje jakiś związek pomiędzy koalicją Saudów i wahhabizmu z tego okresu a obecnym postrzeganiem tego kraju jako państwa wspierającego terroryzm. Można byłoby stwierdzić coś wręcz odwrotnego. Był to okres, $\mathrm{w}$ którym następowała pewna liberalizacja $\mathrm{w}$ tradycji tego kraju. Trzeba przypomnieć, że to właśnie w latach sześćdziesiątych XX w. w Arabii Saudyjskiej powstała pierwsza szkoła dla dziewcząt ${ }^{33}$.

Pewna wspomniana liberalizacja w zakresie tradycji nie mogłaby się bez wątpienia odbyć bez wprzężenia jej w nurt wahhabicki. Oczywiście inną drogą byłoby całkowite porzucenie tej doktryny. Aby jednak wahhabizm mógł dalej funkcjonować w państwie saudyjskim, królowi Fajsalowi udało się do współpracy w zakresie reform wciągnąć saudyjskich alimów. Dzięki temu powstało w latach siedemdziesiątych XX w.

${ }_{29}$ M. al-Rasheed, Dżihad. Narodziny wojującego islamu w Azji Środkowej, przeł. A. Falkowska, M. Falkowski, Warszawa 2003, s. 146-148.

30 Tamże, s. 148.

${ }^{31}$ M. al-Rasheed, Historia Arabii, s. 138.

32 Tamże, s. 148 i n.

${ }^{33}$ E. Machut-Mendecka, Współczesna rodzina muzułmańska, w: E. MachutMendecka (red.), Oblicza współczesnego islamu, Warszawa 2003, s. 75. 
Ministerstwo Edukacji Dziewcząt. Radykalni, ortodoksyjni wahhabici nie bez problemów przyjmowali kolejne nowinki w Arabii Saudyjskiej. Aby przeprowadzać kolejne reformy, poczyniono dalsze ustępstwa na rzecz alimów, szczególnie w zakresie fatw. Stały się one wyrokami religijnymi. Równocześnie rządzący ewidentnie nie zamierzali sprzyjać radykalnemu wahhabizmowi, co udowodnili przez fakt, iż najbardziej bezkompromisowych alimów usunięto. Pewne spory pomiędzy rządzącymi a radykalnymi wahhabitami były jeszcze w dużej mierze pokłosiem konfliktu pomiędzy królem Fajsalem a alimami z 1965 roku, gdy przedmiotem sporu było to, czy stacje radiowe są zgodne $\mathrm{z}$ Koranem ${ }^{34}$.

Sprawa zaczęła się jednak bardziej komplikować, gdy król Fajsal wsparł sprawę palestyńską. Jego polityka przybrała wówczas znamiona islamskiej. Stwierdził, że chciałby modlić się w trzecim świętym dla islamu mieście, jakim jest Jerozolima. Nie były to jednak wszystkie działania z tego okresu promujące islam na świecie podjęte przez Arabię Saudyjską. To również w latach siedemdziesiątych Arabia Saudyjska przyczyniała się do tworzenia poza swymi granicami ośrodków muzułmańskich oraz meczetów. Arabia Saudyjska zaczęła wręcz na masową skalę wzmacniać i szerzyć islam. Trzeba jednak przyznać, iż przywódcy tego kraju, którzy jak wspomniano - budowali meczety na świecie oraz innymi metodami krzewili islam, czynili to jednak metodami pokojowymi. Trudno byłoby zatem uznać, że ich działania wpłynęły na postrzeganie tego kraju jako wspierającego terroryzm. Potwierdzeniem tego było również założenie w 1970 roku generalnego Sekretariatu Ligi Muzułmańskiej. Patronat nad nim objęła Arabia Saudyjska. Z kolei w następnym roku Arabia Saudyjska stwierdziła, iż jest w stanie przeznaczyć znaczne sumy pieniędzy na wspieranie ośrodków kultury muzułmańskiej na całym świecie. Jeżeli natomiast zauważyć, że w 1972 roku powzięto decyzję o wszczęciu świętej wojny przeciw Izraelowi, to bez wątpienia wszystkie te działania wspierały wpływy Arabii Saudyjskiej w świecie muzułmańskim ${ }^{35}$. Można zatem przypuszczać, że taki właśnie był cel władz tego kraju. Wykorzystywano wahhabizm, który jednak często był w oficjalnych komentarzach niejako ukrywany pod nazwą islam, aby nie zrażać innych muzułmanów

\footnotetext{
${ }^{34}$ M. al-Rasheed, Historia Arabii, s. 165-170.

35 Tamże, s. 170-179.
} 
oraz nie niepokoić państw zachodnich. Była to polityka podobna do tej znanej z XVIII w., gdy sojusz saudyjsko-wahhabicki przynosił Saudom największe korzyści. Mimo że Arabia Saudyjska wspierała islam na całym świecie, problemy pojawiły się na jej terenie. W 1979 roku doszło do oblężenia meczetu w Mekce przez terrorystów. Władze co prawda rozwiązały ten problem, jednak dalekim skutkiem tego wydarzenia okazały się liczne ustępstwa rządzących na rzecz radykalnych alimów. Nie był to jednak koniec problemów Saudów w zakresie religii we własnym państwie. W latach 1979-1980 pojawiły się spiski szyickie, które miały osłabić islam wahhabicki. Działania te w oczywisty sposób doprowadziły do odwetu ze strony radykalnych wahhabistów oraz do dalszego umacniania ich pozycji jako stróżów zagrożonego nurtu islamskiego. Równocześnie znaczna część mieszkańców tego kraju w dalszym ciągu nie tylko nie była chętna do zmiany tradycji wahhabickiej, ale wręcz ją mocno kultywowała. Jean Sasson podaje, iż w przypadku tradycyjnego wychowania w Arabii Saudyjskiej trudne nawet do wyobrażenia było dla matki skarcenie małego syna przez wymierzenie kary cielesnej ${ }^{36}$. Należy tu zauważyć, że stwierdzenie to dotyczyło tylko syna, zupełnie inaczej było w przypadku córki. W społeczeństwie zastanawiano się nad szansami pogodzenia wahhabizmu z nowoczesnością. Równocześnie w wahhabizmie widziano szansę na rozwiązanie problemów trapiących Arabię Saudyjską. Następowało coraz wyraźniejsze rozdarcie mieszkańców na tych, którzy pragnęli nowoczesności i kontaktów z Zachodem, oraz tych, którzy chcieli żyć w tradycji wahhabizmu.

Pod koniec lat osiemdziesiątych podziały w Arabii Saudyjskiej na tym tle były jeszcze bardziej jaskrawe. Coraz częściej zdarzało się, że w prawie każdej rodzinie znajdował się człowiek, który wygłaszając kazania wychwalające islam oraz ganiące zachodnią kulturę, oddziaływał na całą rodzinę. Trzeba jednak wspomnieć, iż w tych samych rodzinach nie brakowało osób, które popierały większą otwartość na Zachód. Starsze pokolenie, które często wzbogaciło się na sprzedaży ropy naftowej, było nawet zaszokowane radykalizmem islamskim młodszego pokolenia ${ }^{37}$.

${ }^{36}$ J. Sasson, Córki, księżniczki, sułtany, przeł. G. Gasparska, H. Jankowska, Warszawa 1997, s. 126 i n.

${ }^{37}$ M. al-Rasheed, Historia Arabii, s. 200-206. 
Natomiast obawa przed irackimi szyitami doprowadziła do tego, że Arabia Saudyjska w dużej mierze popierała Irak w jego wojnie przeciw Iranowi. Spowodowało to wielomiliardowe pożyczki dla Iraku, których następnie Irak nie mógł czy też nie chciał spłacać. Cała ta sytuacja przyczyniła się do zajęcia Kuwejtu przez Irak oraz poparcia wówczas Stanów Zjednoczonych przez Arabię Saudyjską ${ }^{38}$. Po raz kolejny skrajni wahhabici wyrażali swoje niezadowolenie ze współpracy z Zachodem. Niezadowolenie to wyrażał także znany później Bin Laden, który po powrocie z Afganistanu w 1989 roku załatwił wizy w Arabii Saudyjskiej około 100 afgańskim mudżahedinom ${ }^{39}$. W tym czasie w Rijadzie odbywały się również protesty ludności domagającej się większego otwarcia na Zachód. Znany stał się wówczas protest kobiet kierujących samochodami. Zakończył się on ich aresztowaniem oraz następnie uwolnieniem po poręczeniu przez ich męskich opiekunów. Umocniło to jednak fundamentalistów w myśleniu, że ich obawy o to, że kraj jest zagrożony wpływami zachodniej kultury są słuszne $e^{40}$. W ten sposób umacniał się nurt wahhabicki w skrajnej swojej postaci w Arabii Saudyjskiej. W 1992 roku przybrał on formę listu około stu fundamentalistów, którzy domagali się, aby media nadawały audycje wspierające islam. Postulowano także, aby werdykty w sądach wydawali islamscy sędziowie. Pewnych problemów w relacjach władzy z alimami przysporzyło opublikowanie listu poza granicami kraju. Władza przyznała, że co prawda alimowie mogą wspierać ich radą, nie powinno jednak dojść do publikacji listu, szczególnie za granicą. Prawdopodobnie rządzący obawiali się rozpowszechniania radykalnego wahhabizmu.

Pewna radykalność niektórych wahhabitów była przez rządzących niejako poskramiana przez przypominanie, że zgodnie z konstytucją Arabii Saudyjskiej król powinien być nie tylko popierany przez społeczeństwo, ale powinno ono mu być wierne i lojalne zgodnie z zasadami Koranu. Pomimo tego nastroje radykalnego wahhabizmu narastały. W 1993 roku powstał w Arabii Saudyjskiej Komitet Obrony Legalnych Praw w Arabii Saudyjskiej. Ze względu na prezentowaną przez niego radykalność

38 Tamże, s. 206-208.

39 J. Sasson, N. Bin Laden, O. Bin Laden, Musiałam odejść, przeł. A. SokołowskaOstapko, Warszawa 2009, s. 131.

${ }^{40}$ M. al-Rasheed, Historia Arabii, s. 218-220. 
religijną jego działalność została niemal natychmiast zabroniona. Nie zaprzestał on jednak całkowicie swojej działalności i przeniósł się do Londynu. Skrajnie wahhabickie poglądy były do tego stopnia nie do zaakceptowania w Arabii Saudyjskiej, iż Rada Najwyższa alimów potępiła tę organizację jako niedozwoloną w kraju, który rządzony jest zgodnie z zasadami islamu. Z kolei al-Fatih proponował koncepcję dla Arabii Saudyjskiej, która mogła się wydawać zbliżona do tej znanej z szyickiego Iranu. Otóż wszystko zmierzałoby wówczas do sytuacji, w której krajem rządziliby uczeni muzułmańscy duchowni ${ }^{41}$. Nieprzyjęcie tej propozycji było bez wątpienia wynikiem tego, iż generalnie we współczesnym islamie ścierają się ze sobą poglądy postępowe i konserwatywne ${ }^{42}$.

Na początku lat dziewięćdziesiątych ubiegłego wieku można było odnieść wrażenie, że grupy fundamentalistów wahhabickich będą w stanie wywrzeć na rządzących taką presję, by nawet i oni zaczęli sprzyjać temu kierunkowi. Przyczyniała się do tego będąca w opozycji do rządzących, fundamentalistyczna grupa o nazwie „Komitet Rady i Reformy”. Jej przywódcą był wspomniany już Osama bin Laden. Przywódcy Arabii Saudyjskiej początkowo byli przychylni tej działalności, jednak po pewnym czasie bin Laden wzmógł krytykę związków Arabii Saudyjskiej z Zachodem. Jego działania doprowadziły do tego, że w 1994 roku został wręcz pozbawiony saudyjskiego obywatelstwa. Dochodziło zatem do sytuacji, w której następował zdecydowany rozdźwięk pomiędzy poglądami religijnymi rządzących a części społeczeństwa. O ile można przyjąć, że przywódcy saudyjscy byli wahhabitami, to jednak starali się wykorzystywać swoją wiarę często dla osiągnięcia korzyści, czy to osobistych, czy też dla podniesienia wpływów samej Arabii Saudyjskiej w świecie. Natomiast społeczeństwo wciąż pozostawało podzielone na tych, którzy byli zwolennikami bliskich związków z Zachodem, oraz tych, dla których wahhabizm w czystej radykalnej formie był natchnieniem do dżihadu miecza.

O pewnym braku tolerancji w Arabii Saudyjskiej pod koniec XX w. może świadczyć fakt, iż chrześcijanie w tym kraju nie byli dobrze traktowani. Nawet chrześcijańscy obcokrajowcy przebywający w Arabii Saudyjskiej nie posiadali, oraz nadal nie posiadają, prawa do gromadzenia

41 Tamże, s. 220-237.

${ }^{42}$ E. Chat, Chrześcijaństwo a islam - polemika i dialog, Kielce 2005, s. 30. 
się i wspólnej modlitwy. Tylko w roku 1992 zostało udokumentowanych ponad 360 przypadków aresztowania wierzących cudzoziemców. Powodem tychże był udział w prywatnych nabożeństwach. Podaje się jednak często, że chrześcijanie na tym terenie nie załamują się tym faktem i szukają nowych dróg wspólnego kultu ${ }^{43}$.

Trzeba zatem przyznać na podstawie uzyskanych informacji, że obecnie wahhabizm służy Arabii Saudyjskiej do poszerzania swoich wpływów w świecie muzułmańskim ${ }^{44}$. Dzieje się tak bez wątpienia w przypadku rządzących. Radykalni wahhabiści nie mają jednak takiego samego celu. Ich celem jest poszerzanie wpływów wahhabizmu. Wobec tego na podstawie niniejszego punktu artykułu można byłoby przyjąć, iż trudno określać Arabię Saudyjską jako kraj wspierający terroryzm. Czynili to jedynie niektórzy jej mieszkańcy. Oczywiście dla pełnego obrazu sytuacji należy jeszcze prześledzić ostatnie lata wahhabizmu w Arabii Saudyjskiej.

\section{ARABIA SAUDYJSKA W XXI W.}

Dwudziesty pierwszy wiek upływa pod hasłem tzw. Arabskiej Wiosny dotykającej wiele państw Bliskiego Wschodu. Jak się okazało, obalenie dyktatorów w krajach tego regionu często powodowało dojście do władzy osób związanych ze skrajnym fundamentalizmem islamskim. Istotne zatem jest znalezienie odpowiedzi, jak w tym przypadku było w Arabii Saudyjskiej. Równocześnie ważna jest ocena zachowania w tej sytuacji samego nurtu wahhabickiego.

Co do samej nietolerancji wobec innych religii niż wahhabizm to można by stwierdzić, że niewiele się w tym czasie zmieniło w Arabii Saudyjskiej. Otóż w raporcie o prześladowaniach chrześcijan w państwach muzułmańskich z 2005 roku stwierdzono, że w kraju tym mieszka około 6 milionów imigrantów, z czego większość to chrześcijanie. Przyznano jednocześnie, że wszelki kult poza islamem jest tam zabroniony. Zatem w tym przypadku trudno byłoby oskarżać jedynie skrajnie radykalnych wahhabistów o takie postępowanie. Odpowiedzialność za taką sytuację

\footnotetext{
${ }^{43}$ K. Kościelniak, Dżihad. Święta, s. 111 i n.

44 Tamże, s. 55-57.
} 
ponoszą bez wątpienia władze kraju. Równocześnie we wspomnianym raporcie zauważono, że mimo iż licznym aresztowaniom chrześcijan w tym kraju towarzyszy znaczna krytyka, są one kontynuowane. Trzeba jednocześnie zaznaczyć, że najdotkliwsza nietolerancja jest skierowana wobec chrześcijan niepochodzących z Zachodu. Są to głównie pakistańscy i filipińscy robotnicy. Policja religijna zajmuje się często ściganiem osób zaledwie podejrzewanych o chrześcijaństwo. Prześladowani są w tym względzie głównie saudyjscy konwertyci. W zasadzie już sam fakt posiadania Biblii może przysporzyć właścicielowi wielu problemów. Jednocześnie zauważono, że podobnie jak w poprzednim stuleciu Arabia Saudyjska finansuje budowy meczetów na całym świecie, zabraniając równocześnie postawienia na swoim terytorium chociażby kaplicy. Przykłady dyskryminacji w tym kraju są często bardzo jaskrawe. W październiku 2004 roku hinduski chrześcijanin został skazany na 10 miesięcy więzienia i 300 razów chłosty za sprzedaż alkoholu. Dopiero po międzynarodowej interwencji skończyło się jedynie na chłoście. Z kolei w marcu 2005 roku u chrześcijanina pochodzenia hinduskiego znaleziono Biblię, za co został aresztowany. W kwietniu 2005 roku aresztowano około 40 osób, głównie Pakistańczyków, którzy uczestniczyli w nabożeństwie u jednego z nich ${ }^{45}$. Można w tym przypadku przyznać, że władze saudyjskie, chcąc przypodobać się skrajnym wahhabistom lub też zmniejszyć ich ewentualne oddziaływanie terrorystyczne, decydowały się na pewne kroki, które kojarzyć się mogły właśnie z radykalnym wahhabizmem. Z drugiej jednak strony należy zauważyć, iż władze nie stosowały terroryzmu, ani też do niego nie namawiały. Równocześnie warto $\mathrm{w}$ tym miejscu przypomnieć fakt, że gdy władze Arabii Saudyjskiej uzyskiwały zgodę na budowę meczetu w Rzymie, zobowiązały się wówczas do tego, że zaniechają prześladowań chrześcijan w swoim kraju ${ }^{46}$. Prawdopodobnie radykałowie utrudnili spełnienie tej obietnicy.

Klęska talibów w Afganistanie bardzo zmartwiła wielu saudyjskich teologów muzułmańskich. Twierdzili oni, że stworzone przez talibów państwo było najbardziej zbliżoną wersją idealnego państwa opartego na

${ }^{45}$ G. Kucharczyk, Pod rządami pótksiężyca, Poznań 2006, s. 91 i n.

46 Tamże, s. 46 i n. 
doktrynie wahhabickiej ${ }^{47}$. W związku z tym skrajni wahhabiści bardzo chętnie przyjmowali bojowników z terenu Afganistanu do swego kraju. Działania te nie były jednak popierane przez króla oraz wspierających go alimów. Ich działania nadal były bowiem w większości wypadkową chęci liberalizacji kraju w oparciu na wahhabizmie oraz uspokojenia radykalnych wahhabistów. W związku z taką sytuacją pojawienie się w tym kraju talibów doprowadziło do tego, że w latach 2003-2005 praktycznie każdego miesiąca służby bezpieczeństwa musiały interweniować w sprawach fundamentalistycznych terrorystów. W tym czasie jednak talibom w różnego rodzaju zamachach udało się zabić w samej Arabii Saudyjskiej ponad dwieście osób. Doprowadzili oni w ten sposób do naruszenia dobrego wizerunku tego kraju jako oazy spokoju i dobrobytu w porównaniu z innymi krajami regionu. Rząd Arabii Saudyjskiej próbował odciąć się od działań terrorystycznych. Był gotów nawet na tak daleko posunięte stwierdzenie na arenie międzynarodowej, że wahhabizm nie jest z Arabią związany. Jednak gdy przemoc pojawiła się w saudyjskich miastach w 2003 roku, szybko okazało się, że al-Ka’ida została niejako wyhodowana w samej Arabii Saudyjskiej na gruncie teologii wahhabickiej. Wówczas to w wielu pismach saudyjskich cytowano wielu ojców założycieli ruchu wahhabickiego. W ogarniającej kraj fali przemocy skrajni wahhabici szukali uzasadnienia dla swoich działan. Równocześnie ogromna fala przemocy spowodowała wystąpienia liberalnych saudyjskich intelektualistów, którzy oskarżali rząd o to, że po oblężeniu meczetu w 1979 roku dał zbyt wiele swobód elicie religijnej oraz próbował w pewien sposób z nią współpracować. Stwierdzono też, że przez różne akcje dobroczynne, takie jak letnie obozy, doprowadzono do tego, że wahhabickie kaznodziejstwo zaczęło przenikać nawet do struktur rządowych. W ten sposób wahhabizm stał się kontestowaną sektą. Bronili jej jednak radykalni alimowie.

Należy tu równocześnie zaznaczyć, że jeszcze przed XXI w. wahhabizm podzielił się na różne nurty. Niektórzy alimowie zajmowali wysokie pozycje na dworze królewskim jako doradcy. To oni najczęściej sprzeciwiali się radykalizacji wahhabizmu. Istnieli także tzw. Kadich, którzy zajmowali się strzeżeniem władz przed destabilizacją. Z drugiej jednak strony nie brakowało młodych kaznodziejów, którzy utrzymywali, że

${ }^{47}$ M. al-Rasheed, Historia Arabii, s. 291-293. 
pozostają wierni teoriom al-Wahhabiego. Atakowali oni alimów, których nazywali alimami sułtanów, ze względu na to, iż uważali, że wydawane przez nich fatwy były podporządkowane celom politycznym rządzących. Stąd też owi kaznodzieje w pewnym momencie zaczęli wzywać do dżihadu przeciw niewiernym oraz przeciw saudyjskim służbom bezpieczeństwa ${ }^{48}$. Przytaczano często wydarzenia z oblężenia meczetu w 1979 roku, przyznając równocześnie, że współcześnie Mekka pełni funkcję integrującą dla Arabów z Półwyspu Arabskiego ${ }^{49}$. W związku z tym niejako pewnym następstwem był, skierowany 13 marca 2003 roku przez saudyjskich intelektualistów liberalnych list do prezydenta Stanów Zjednoczonych, w którym $\mathrm{z}$ radością przyjęli informację o demokratyzacji w Iraku. Równocześnie domagali się oni zdecydowanych reform liberalizujących w swoim kraju ${ }^{50}$. Potwierdza to w pewnym sensie opinię Stephane Marchanda, który pisał, że pomimo tego, iż niemal cały świat uważa Arabię Saudyjską za kraj wahhabicki, to mieszkańcy tego kraju uważają to sformułowanie za obraźliwe ${ }^{51}$. Warto jednak w tym miejscu przypomnieć, iż al-Kaida uważała się za obrończynię sunnitów. Działo się tak w sytuacji, gdy równocześnie król saudyjski Abd Allah zauważał, iż odradza się tzw. szyicki półksiężyc. W ten sposób można było podejrzewać, że wahhabicki król chciał za pomocą prześladowanej przez siebie organizacji terrorystycznej rozwiązać ten problem. Jednakże w takim przypadku nie można pominąć faktu, iż to dzięki saudyjskiemu pośrednictwu doszło w Mekce do spotkania irackich szyitów i sunnitów, którzy zobowiązali się do tego, iż nie będzie przelewana muzułmańska krew. Natomiast w 2006 roku reputacja religijna Arabii Saudyjskiej w świecie arabskim mocno ucierpiała ze względu na fakt, iż jej król nie potrafił pogodzić walczącego Hezbollahu z Izraelem ${ }^{52}$.

Nieco wcześniej, bo w 2003 roku ujawnili się w tym kraju ismailici z Nadżranu, którzy zaczęli domagać się praw, przysługujących im jako obywatelom tego saudyjskiego państwa. Równocześnie zażądali wycofania fatw, które wykluczały ich z islamu. Wówczas podniosły głos

48 Tamże, s. 295 i n.

49 H. Jamsheer, Jedność arabska w perspektywie historycznej, w: E. MachutMendecka (red.), Oblicza współczesnego islamu, s. 81.

50 M. al-Rasheed, Historia Arabii, s. 298 i n.

51 S. Marchand, Arabia Saudyjska, przeł. R. Stryjewski, Warszawa 2004, s. 22.

52 M. al-Rasheed, Historia Arabii, s. 330 i n. 
również inne grupy, które zaczęły krytykować doktrynę wahhabicką. Uczynili tak również sufi. Przez długie lata karano ich za odwiedzanie grobów świętych oraz obchodzenie urodzin Proroka. Doprowadziło to do sytuacji, w której zaczęło się pewne zrównywanie praw religijnych zarówno szyitów, jak i ismailitów ${ }^{53}$. Nie można jednak nie zauważyć, iż nawet jeśli przyjąć, że pewne grupy muzułmanów w Arabii Saudyjskiej były przez długie lata dyskryminowane przez władze, to działania te nie miały charakteru terrorystycznego.

Bez wątpienia władze tego kraju przez wiele lat były zainteresowane tym, aby świat muzułmański postrzegał je jako religijne. Trzeba dlatego zauważyć, że królowie Arabii Saudyjskiej po dziś dzień noszą tytuł Strażnika Dwóch Świętych Meczetów, co ma właśnie wymiar religijny. Równocześnie należy tu przypomnieć, iż następcy tronu, którzy są mianowani przez króla, muszą uzyskać zgodę nie tylko domu Saudów, ale także ulemów, którzy są teologami islamskimi. Umacnia to również religijny charakter władzy. Jednocześnie sama władza króla jest w pewien sposób ograniczona religijnie, gdyż nakłada na króla konieczność konsultacji. Wynika to $\mathrm{w}$ dużej mierze $\mathrm{z}$ tego, że $\mathrm{w}$ tym kraju po dziś dzień oprócz prawa religijnego występuje prawo świeckie. Przyjmuje się, że początkowo było ono równe z sunną. Należy także przyznać, iż co prawda najważniejszym aktem prawnym Arabii Saudyjskiej jest Podstawowe Prawo o Sprawowaniu Rządów będące aktem świeckim z 1992 roku, które wraz z kilkoma innymi aktami tworzy niejako małą konstytucję, to jednak w zasadzie dokumenty te nie są zbyt istotne, jako że muszą być zgodne $\mathrm{z}$ Koranem i sunną. To one w zasadzie tworzą najwyższe prawo Arabii Saudyjskiej, stanowiąc wręcz konstytucję ${ }^{54}$. W tym miejscu należy przypomnieć, iż w saudyjskim systemie prawnym nadal znaczącą rolę odgrywają ulemowie ${ }^{55}$-alimowie. Są oni grupą muzułmańskich uczonych, których można określać mianem znawców teologii. Mogą oni również w obecnych czasach wydawać wspominane tzw. fatwy, czyli opinie, których moc zależy od autorytetu danego ulema. Konieczne wydaje się także

53 Tamże, s. 344 i n.

${ }^{54}$ G. Małachowski, System konstytucyjny, s. 22n.

55 Ulemowie - jako polskie określenie, alimowie - określenie stosowane w większej części artykułu - jest pochodzenia arabskiego, wydaje się w niektórych przypadkach bardziej dopasowane do saudyjskiego systemu. 
wspomnienie o tym, iż na szczycie hierarchii alimów stoją członkowie rodziny Abd al-Wahhaba. Równocześnie najwyższy z alimów nazywany jest wielkim muftim. Stoi on na czele utworzonej w 1971 roku Rady Starszych Ulemów (Alimów). Rada składa się z 20 członków mianowanych przez króla na czteroletnie kadencje. Rada stwierdza zgodność królewskich dekretów z prawem Koranu i sunny. Uczeni islamscy stoją także na czele Ministerstwa Sprawiedliwości. Wybitni ulemowie prowadzą też programy telewizyjne, w których udzielają rad. Sytuacja mniej znaczących jest znacznie trudniejsza. Muszą oni wygłaszać mowy na ulicach oraz w meczetach. Swobodę ich wypowiedzi ograniczył dopiero dekret królewski, zgodnie z którym opinie generalne mogą wydawać jedynie członkowie Rady Starszych Ulemów. Natomiast najniższą warstwą ulemów są muttawowie. Są oni zobowiązani do zagwarantowania porządku w postaci np. konieczności zamykania sklepów podczas modłów oraz w ogóle tego, aby mężczyźni się modlili. Muszą oni także dbać o to, aby nie były celebrowane inne obrządki islamu niż sunnicki. Powinni dbać o to, aby stroje kobiet całkowicie zakrywały ich ciało oraz o to, aby zapobiegać kontaktom kobiet i mężczyzn niespokrewnionych. Znani są oni z brutalności wobec szyitów $^{56}$. System ten wyraźnie ukazuje, iż wyżej postawieni w hierarchii alimowie, będący często zależni od króla, zapewne są bardziej skorzy do wydawania opinii zgodnych z aktualną polityką władz. Z kolei niżej postawieni alimowie, nie będąc obarczeni brzemieniem współpracy z władzą, chętniej promują wahhabizm w czystej postaci.

W związku z tym odpowiedź na pytanie, czy Arabia Saudyjska jako kraj o wahhabickiej doktrynie religijne ma podstawy do bycia krajem nietolerancyjnym oraz wspierającym międzynarodowy terroryzm, wydaje się nadal trudna. W powyższym punkcie artykułu zostały przedstawione grupy społeczne z tego kraju, które bez wątpienia można byłoby przyjąć za pewną podstawę do uznania ich za wspierające międzynarodowy terroryzm. Z drugiej jednak strony należy stwierdzić, że władze tego kraju były oraz są przeciwne działalności terrorystycznej jako modelowi propagowania doktryny wahhabickiej. W związku z tym, biorąc pod uwagę, że doktryna wahhabicka zakłada saudyjskie przywództwo, w tym przypadku rodziny królewskiej, można zakładać, że radykalne grupy wahhabickie

${ }^{56}$ G. Małachowski, System konstytucyjny, s. 53. 
nie mają szans dojścia do władzy. Zatem nasuwa się wniosek, że Arabia Saudyjska jako kraj nie może być posądzana o wspieranie terroryzmu opartego na doktrynie wahhabickiej.

\section{ZAKOŃCZENIE}

Odpowiedź na pytanie zawarte we wstępie tego artykułu okazała się bardzo trudna. W pierwszej jego części, gdzie przedstawiono Arabię Saudyjską przed pojawieniem się tam doktryny wahhabickiej, można było dostrzec, iż sam islam w VIII w. rozwijał się z użyciem przemocy. Równocześnie $\mathrm{z}$ tych samych podstaw korzystały także inne nurty islamu. $\mathrm{Z}$ tego też powodu trudno byłoby te korzenie przypisać wyłącznie wahhabistom. Kolejna część pracy ukazała okres powstania doktryny wahhabickiej oraz jej sojusz z Saudami. W tym przypadku ekspansja za pomocą przemocy była ewidentna, jednak stosujący ją Saudowie nie tyle byli głosicielami tej idei, ile zdobywcami wykorzystującymi ją dla celów politycznych. Następny punkt artykułu zawierał informacje o doktrynie wahhabickiej w niepodległym państwie, jakim stała się Arabia Saudyjska. Jako że był to czas, w którym nastąpiło bardzo wiele istotnych zdarzeń, punkt ten jest najbardziej obszerny. W jego ramach udało się ustalić, iż o ile w początkowych latach tego państwa doktryna wahhabicka nie miała bardzo istotnego znaczenia w stosunkach społecznych, to już kolejne lata powodowały znaczące rozgraniczenie pomiędzy tymi obywatelami, którzy pragnęli większego otwarcia kraju na Zachód, a tymi chcieli trwać przy wahhabizmie w czystej formie. Ostatni punkt pracy ukazał z kolei istnienie wielu grup społecznych w Arabii Saudyjskiej, które w swoim dążeniu do utrzymania pewnej tradycji są skłonne do stosowania terroryzmu. Równocześnie władze kraju starają się utrzymywać pewną równowagę pomiędzy właśnie tymi grupami, z którymi często prowadziły prawie otwartą wojnę, a tą częścią społeczeństwa, która domaga się liberalizacji kraju. Mając to wszystko na uwadze, trudno uznać, że Arabia Saudyjska o doktrynie wahhabickiej ma rzeczywiste podstawy do bycia krajem skrajnie nietolerancyjnym oraz wspierającym międzynarodowy terroryzm. 
Streszczenie. Problemy religijne Arabii Saudyjskiej. Arabia Saudyjska jest krajem, który często w światowych mediach bywa określany jako wspierający międzynarodowy terroryzm. Równocześnie duże znaczenie w tym zakresie przypisuje się islamskiej doktrynie wahhabickiej, która tam obowiązuje. Dlatego też interesujące wydaje się zweryfikowanie tego, czy rzeczywiście kraj ten, uznający doktrynę wahhabicką, ma podstawy ku temu, aby być tak określanym. W celu uzyskania odpowiedzi dokonano charakterystyki obszaru dzisiejszej Arabii Saudyjskiej przed pojawieniem się wspomnianej ideologii. Następnie przedstawiono doktrynę wahhabicką z jej konsekwencjami dla Saudów. Kolejna część artykułu ukazuje powiązanie wahhabizmu z Saudami w okresie istnienia państwa Arabia Saudyjska. Ostatnia część ma za zadanie ukazanie wspomnianych powiązań w XXI w. Przedstawione części pracy powinny pomóc w uzyskaniu odpowiedzi na postawione pytanie.

Słowa kluczowe: wahhabizm; islam; Arabia Saudyjska; Arabowie; terroryzm.

Summary. Religious problems in Saudi Arabia. Saudi Arabia is a country that is often suspected to promote terrorism. The key role seems to be played by the country's leading ideology, i.e. Wahhabism. To find the answer on Wahhabism role in the Saudi internal and foreign policy, the paper describes the Arabian Peninsula in its pre-Islamic times. Next the influence of the Wahhabism on the Saudi state will be examined. Another important factor the paper deals with is the bond of the Saudi people with Wahhabism in Saudi Arabia in the past and today.

Keywords: Wahhabism; Muslims; Saudi Arabia; Arabs; terrorism. 
